\title{
Undergraduate allergy teaching in a UK medical school: mapping and assessment of an undergraduate curriculum
}

\author{
Yasser Shehata, Michael Ross, Aziz Sheikh*
}

\author{
Division of Community Health Sciences: GP Section, University of Edinburgh, 20 West Richmond St, \\ Edinburgh EH8 9DX, UK
}

Received 26 March 2006; accepted 2 April 2006

\begin{abstract}
KEYWORDS
Allergy;

Medicine;

Undergraduate training;

Medical education;

Standards of care

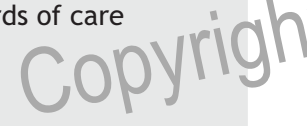

Summary

Background: Concerns have been expressed by pationt and protessionat bodies, and the UK Parliamentary Health Select Com A ittee iliout the poor standard of allergy teaching in UK medisal schoots (It, is argued that this deficiency is an important contributing factor o the generally poor fuatl t $\mathrm{t} \nabla \mathrm{f}$ care experienced by patients with alleigio disorders. Allergy services aie firrertily being reviewed by the Scottish Executive and Pepart inent fo Health for England.

Objective: 1) aescribe and map the teaching of allergy-related topics in the formal uncergraduate curriculum of a UK medical school.

Methods: We undertook a systematic analysis of learning objectives and other electronic documentation of modules taught during the five years of undergraduate medical training at the University of Edinburgh.

Results: Allergy and allergy-related topics are mentioned within the learning objectives of $11(26 \%)$ of the 43 modules in the five-year MBChB curriculum. Our overall assessment reveals significant gaps in the described curriculum regarding allergy-related topics.

Conclusion: Although formal teaching on allergic disorders has been identified in a number of modules throughout the five years, it is not comprehensively described in the course documentation and significant gaps exist. We accept that the delivered curriculum may not be captured by the level of detail present in the learning objectives and recommend that further mapping and triangulation is undertaken through student focus groups and information gathering from teaching staff. We also recommend that in the absence of informal and clinical attachment opportunities in allergic disorders, the stated learning objectives be developed into a coherent vertical element throughout the medical curriculum. This, together with an advocate and suitable assessment, would increase the impact of allergy training on students and emphasise the knowledge and skills required to deliver high quality allergy care. (c) 2006 General Practice Airways Group. Published by Elsevier Ltd. All rights reserved.
\end{abstract}

* Corresponding author. Tel.: +44 (0)131 651 4151; fax: +44 (0)131 6509119.

E-mail address: aziz.sheikh@ed.ac.uk (A. Sheikh). 


\section{Introduction}

Approximately one in three of the UK population experience an allergic problem during their lifetime, resulting in considerable morbidity to the individuals concerned and a substantial economic burden to the National Health Service [1-3]. Whilst allergy services are well developed in many other Western countries, this is not true of the UK, as has been highlighted in the Royal College of Physician's recent report Allergy: The unmet need [4]. The conclusions of this report have subsequently been endorsed by the UK Parliamentary Health Select Committee [5].

It has been argued that the deficiencies underpinning poor allergy provision in the UK are multi-factorial, including, amongst other things, a low baseline of knowledge and skills throughout the medical profession $[6,7]$. This in turn is believed to reflect the lack of adequate training opportunities in UK undergraduate medical curricula. There is, however, a dearth of empirical evidence underpinning this assertion.

In common with most UK medical schools, the University of Edinburgh curriculum underwent significant review and restructuring following the General Medical Council's influential publication Tomorrow's doctors in 1993 [8]. This lec to the traditional discipline-based curricullon being replaced by an integrated sy-erns-Dased spiral curriculam vivit] a rnodylar structure in $19 \% 8$ [9]. A. documentacion relating to the deiveled curriculum is available electronically to staif and students via a managed learning environment called the Edinburgh Electronic Medical Curriculum (EEMeC) $[10,11]$.

We sought to describe and map the teaching of allergy-related topics throughout the University of Edinburgh's undergraduate medical curriculum.

\section{Methods}

Using EEMeC we identified all taught modules during the five year $M B C h B$ course and defined other significant units of teaching which were not described under these module headings. Learning objectives for each of these modules were extracted in full and collected into a database.

We also sought to identify whereabouts in the curriculum allergy and allergy-related conditions are taught, by electronically searching all course documents in EEMeC for the following key terms: Allergen; Allergens; Allergic; Allergic conjunctivitis; Allergy; Allergy diagnosis; Anaphylactic; Anaphylaxis; Angioedema; Asthma;
Asthmatic; Atopic; Atopy; Desensitisation; Eczema; Food allergy; Hay fever; Hypersensitivity; Oral allergy syndrome; Perennial rhinitis; Seasonal rhinitis; and Urticaria. Documents containing any of these terms were also extracted in full and collected into the database.

A detailed manual documentary analysis of these course materials was then undertaken independently by two medically qualified physicians, and data were abstracted; any disagreements were resolved through discussion, with a third reviewer arbitrating if agreement could not be reached. This involved looking for text in which allergic disorders were specifically mentioned, but excluding general references which may have included allergic disorders. A good example of such an exclusion was in the year 3 respiratory module, which includes learning objectives on history-taking and diagnosis of wheeze, and "for each of the respiratory diseases covered in the diet of lectures you should be able to describe the relevant epidemiology, pathogenesis, clinical features... investigations and their interpretation, and principles of management (including prevention where appropriate)." There was no documentationfrelating to the content of the lect liks cr the specific diseases studied; hoivere; the authors know that one of the major diseases studiec Qurng this module is asthma. This (is therefore a clear example of course documentation not actually reflecting the teaching of the module.

\section{Results}

A total of 43 distinct units of teaching were identified within the five-year MBChB curriculum (Table 1). Of these, 38 were discrete course modules and five were 'Curriculum Vertical Themes', which are discrete subject areas taught in a progressive manner throughout the five years (these are henceforth described as 'modules' for the purposes of this paper). One of the vertical themes, entitled 'Student Selected Components', allows students to study a very diverse range of noncompulsory subjects, some of which may relate to allergies. Similar student-selected components now exist in most medical curricula [12].

Documentation from 11 (26\%) of the 43 modules contained explicit reference to allergy-related topics (Table 2). Detailed analysis revealed that asthma was the most comprehensively described allergic disorder, followed by eczema and anaphylaxis; there was also some mention of teaching of allergic rhinitis and urticaria. There 
Table 1 Learning Objectives relating to allergy teaching within course modules

\begin{tabular}{|c|c|c|}
\hline Year of study & Course module/identified unit of teaching & $\begin{array}{l}\text { Specific learning objectives } \\
\text { on allergic disorders }\end{array}$ \\
\hline Years 1 \& 2 & $\begin{array}{l}\text { Introduction to Life } \\
\text { Cardiovascular Health } \\
\text { Respiration } \\
\text { Bones \& Joints } \\
\text { Neuroscience } \\
\text { Nutrition } \\
\text { Clinical Genetics } \\
\text { Renal } \\
\text { Endocrinology } \\
\text { The Virtual Clinic } \\
\text { Introduction to Clinical Practice } \\
\text { Health \& Society } \\
\text { Problem-Based learning }\end{array}$ & $\begin{array}{l}\text { Yes } \\
\text { No } \\
\text { Yes } \\
\text { No } \\
\text { No } \\
\text { No } \\
\text { No } \\
\text { No } \\
\text { No } \\
\text { No } \\
\text { Yes } \\
\text { No } \\
\text { Yes }\end{array}$ \\
\hline Year 3 & $\begin{array}{l}\text { Locomotor System } \\
\text { Gastroenterology } \\
\text { Respiratory System } \\
\text { Cardiovascular System } \\
\text { Psychiatry }\end{array}$ & $\begin{array}{l}\text { No } \\
\text { No } \\
\text { Yes } \\
\text { No } \\
\text { No }\end{array}$ \\
\hline Year 4 & $\begin{array}{l}\text { Oncology \& Palliative Care } \\
\text { Psychiatry } \\
\text { Neurology } \\
\text { General Practice } \\
\text { Obstetrics \& Gynaecology } \\
\text { Renal Medicine } \\
\text { Urology } \\
\text { Haematology } \\
\text { Breast } \\
\text { c) Odryrisology } \\
\text { Dermatology } \\
\text { Ophth inciog. } \\
\text { Genitourinary Medicine }\end{array}$ & $\begin{array}{l}\text { No } \\
\text { No } \\
\text { No } \\
\text { No } \\
\text { No } \\
\text { vo } \\
\text { No } \\
\text { No } \\
\text { No } \\
\text { Yes } \\
\text { Yes } \\
\text { No } \\
\text { No }\end{array}$ \\
\hline Year 5 & $\begin{array}{l}\text { Child Life \& Health } \\
\text { Geriatric Medicine } \\
\text { General Practice } \\
\text { Acute \& General Medicine } \\
\text { General Surgery } \\
\text { Anaesthetics, Critical Care, A\&E }\end{array}$ & $\begin{array}{l}\text { No } \\
\text { No } \\
\text { Yes } \\
\text { Yes } \\
\text { Yes } \\
\text { No }\end{array}$ \\
\hline All 5 Years & $\begin{array}{l}\text { Pharmacology \& Therapeutics } \\
\text { Social Sciences \& Public Health } \\
\text { Psychological Aspects of Medicine } \\
\text { Clinical Skills, Personal Professional Development } \\
\text { Student Selected Components }\end{array}$ & $\begin{array}{l}\text { Yes } \\
\text { No } \\
\text { No } \\
\text { No } \\
\text { No }\end{array}$ \\
\hline
\end{tabular}

were, however, important omissions of individual disorders - for example, angioedema and food allergy.

In some instances there were documented learning objectives about conditions which encompass allergic disorders, but are non-specific, such as "You should be able to describe the cause and management of a patient presenting with... conjunctivitis". No documentation was identified relating to the concept of allergy prevention, allergy investigation and diagnosis, or desensitisation therapy.

\section{Discussion}

This analysis of the University of Edinburgh's formal undergraduate medical curriculum has found that 
Table 2 Detailed allergy teaching within the module learning objectives

\begin{tabular}{|c|c|}
\hline Year & Module and description of subjects covered \\
\hline Years 1 \& 2 & $\begin{array}{l}\text { Introduction to Life } \\
\text { Cells to organs } \\
\text { (lectures \& learning objectives on acute and chronic inflammation) } \\
\text { Defending the body } \\
\text { (lectures \& learning objectives on the immune system, antibodies and antibody technology) } \\
\text { Respiration } \\
\text { Physiology and biochemistry } \\
\text { With respect to changes in lung function in obstructive and restrictive disorders, the student } \\
\text { should be able to name the main types of obstructive disorders of asthma and chronic obstructive } \\
\text { pulmonary disease } \\
\text { Drugs and respiratory disease } \\
\text { For each of the major lung diseases (COPD, asthma) list the main classes of drug used to treat the } \\
\text { disorder and explain why the chosen drugs are appropriate } \\
\text { Describe the unwanted effects of (NSAIDs) on the airways in bronchial asthma } \\
\text { Immunology } \\
\text { In relation to the inappropriate immune responses students should be able to: } \\
\text { - Explain the concept of hypersensitivity reactions } \\
\text { - Describe the processes responsible for each of the four types of hypersensitivity reaction and } \\
\text { illustrate each with appropriate examples } \\
\text { Introduction to Clinical Practice } \\
\text { Respiratory system illustrative diseases: Asthma \& COPD } \\
\text { Problem-Based learning } \\
\text { There is a Problem-Based learning topic in Semester } 2 \text { (which is designed to integrate hiomedicine } \\
\text { and social sciences) based on a case of Bakers' asthma }\end{array}$ \\
\hline Year 3 & $\begin{array}{l}\text { Respiratory System } \\
\text { The student should be able to decrribe the tho ogical processes underlying allergy }\end{array}$ \\
\hline Year 4 & 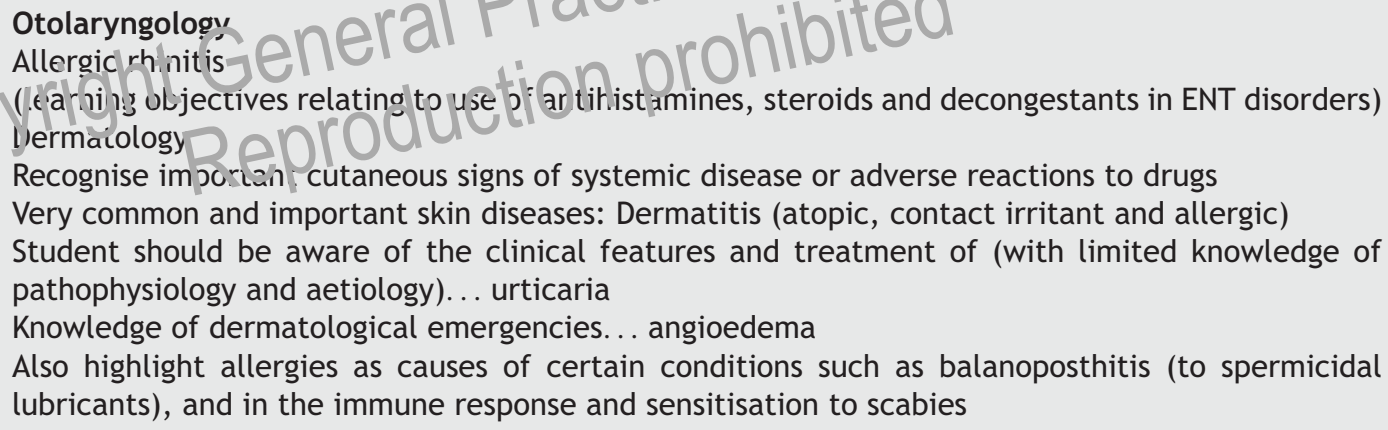 \\
\hline Year 5 & $\begin{array}{l}\text { General Practice } \\
\text { Be able to formulate \& justify a continuing care programme for the following common continuing } \\
\text { conditions largely managed in the community: asthma } \\
\text { To learn the core therapeutic drugs and problems (Severe asthma, Acute anaphylaxis, Allergy) } \\
\text { Acute/General Medicine } \\
\text { The student should be aware during Breathlessness patient's medical history taking of } \\
\text { wheeze/Asthma/stridor, cough/sputum/smoking } \\
\text { By the end of the attachment you should be able to describe the clinical features and pathogenesis } \\
\text { of common medical conditions, and outline their immediate management... Severe asthma } \\
\text { General Surgery } \\
\text { Describe pathophysiology of the common forms of shock (hypovolaemic, septic, anaphylactic, } \\
\text { neurogenic and cardiogenic) }\end{array}$ \\
\hline All 5 Years & $\begin{array}{l}\text { Pharmacology \& Therapeutics } \\
\text { Core therapeutic problems... asthma, eczema and allergic rhinitis } \\
\text { Case on anaphylaxis } \\
\text { Core skills... Drug history: recording current and past adverse drug reactions and allergies } \\
\text { Allergy, asthma and eczema in the context of paediatric and child health }\end{array}$ \\
\hline
\end{tabular}


allergy and allergy-related disorders are currently taught throughout the five years of undergraduate training. However, mapping of allergy-related topics using curriculum documentation indicates significant topics which appear not to be covered - such as food allergy, allergy investigation and diagnosis, and management of those patients with multi-organ allergic disease. Our findings also suggest a need to pull together the disparate components of the allergy curriculum into a coherent theme.

\section{Main strengths and limitations of this work}

The principal strengths of this work are the systematic manual searching of all course learning objectives and electronic searches of all core course documentation throughout the five years of study.

The main limitations of this study are that it was confined to one medical school and focused on the formal described curriculum. Although the curriculum in each UK medical school is different, and there are some very different approaches to teaching and learning in some (for example, Glasgow University's predominantly problem-based learning approach), Edinburgh is a fairly typical example of the integrated systems-based uricula which many medical chopols ivevel aciopted in

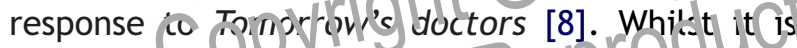
impossible to 5 enevalise broac IV frim our tirdings, we are not aware of any other medical schools in the UK highlighting allergic disorders as a key theme, and so they are likely to have similarly incomplete documentation relating to the teaching of these disorders.

Probably the most significant limitation was that we were unable to make any formal assessment of students' actual knowledge, attitudes, or skills in relation to the management of allergic problems. This is important, since there is often considerable difference between planned, described, and delivered curricula, and also between delivered and learned curricula [13]. The lack of detail in the learning objectives may also be misleading, as we found some examples of topics which could possibly include allergic disorders but in which this was not made explicit (such as conjunctivitis and inflammation). Also, whilst the managed learning environment search engine would identify key terms within the majority of course documentation (encoded in html), it would not identify these in text embedded within PowerPoint presentations, Word documents, or Adobe Acrobat files.
Given the high prevalence of allergic disorders it is likely that students will come into contact with patients suffering from these disorders and may receive opportunistic informal teaching about them in most clinical attachments. Due to the lack of allergy specialist services in Edinburgh, however, the opportunities for students to receive structured, comprehensive and cohesive informal training about allergic disorders as a whole are likely to be minimal, and we feel that such teaching should not be left to chance.

\section{Considering these findings in relation to the published literature}

Although allergy and allergy-related topics are covered throughout the formal medical curriculum, there appear to be important deficiencies in the way allergic disorders are described and presented to students. A recent national survey has revealed general practitioners' lack of confidence in managing patients with, for example, possible food allergies, those with multiple allergies, and in interpreting related diagnostic tests [14] $\mathrm{I}$ view of the overlap between these ar eas and the gaps we have identified in the tescribed curriculum, these shottconfing; clearly need to be addressed.

\section{Eonciusions: implications for curriculum clevelopment and research}

Given the frequency of allergy, its typical multi-organ manifestations, and the lack of informal and specialist clinical training opportunities available, it is important that a more coherent approach to teaching allergy is developed at undergraduate level. Identifying and developing allergy as a curriculum vertical element should be relatively straightforward. This would involve: appointing an advocate for the theme; negotiating learning objectives; developing the curriculum map we have created on the managed learning environment in order to emphasise to students and staff how and where allergic disorders are taught; highlighting and addressing any omissions or weaknesses; and supporting the teaching and learning of allergic disorders with written materials, computer-aided learning packages, and other resources [15,16]. The University of Edinburgh has recently undertaken a similar approach to curricular development with respect to the key clinical themes 'Alcohol', 'Disability' and 'Diabetes', and has, through this approach, improved the comprehensiveness and coherence of the training provided in these areas. 
Highlighting allergic disorders in this way will now be formally proposed to the Edinburgh Medical Undergraduate Studies Committee.

In addition, we recognise the need to gather information from module organisers to identify teaching in their modules on allergic disorders which is not currently described in the learning objectives - i.e. to compare the delivered curriculum with the described curriculum. We also plan to organise focus groups of students to identify their learning in allergic disorders in order to compare student learning with the described curriculum.

Thinking strategically, and beyond the confines of Edinburgh, and with the Scottish Executive and the Department of Health currently reviewing allergy services, there may also be merit in developing a core allergy curriculum that can be adapted for use in all UK medical schools.

\section{Potential conflict of interests}

Aziz Sheikh gave evidence to the Health of Commons Health Committee review on The provision of allergy services, is part of the Department of Health Allergy Review Stakeholder Group and serves on the Scottish Executive's Review of Allergy Services in Scotland Working Groulp.

Michael Ross is a member of the Qriversity of Edinburgh's Medical Todching o yurrisation.

Yass S S nehay a has o conflicts of inteits

\section{Acknowledgments}

Our thanks to Dr Helen Cameron, Director of the University of Edinburgh's Medical Teaching Organisation, for constructively commenting on an earlier draft of this manuscript.

Aziz Sheikh conceived the idea for this study and together with Michael Ross devised the methodology. Yasser Shehata and Michael Ross undertook data analysis. All three authors were involved in writing the paper.

Funding: None.

\section{References}

[1] The International Study of Asthma and Allergies in Childhood (ISAAC) Steering Committee. Worldwide variation in prevalence of symptoms of asthma, allergic rhino-conjunctivitis, and atopic eczema: ISAAC. Lancet 1998;351:1225-32.

[2] European Community Respiratory Health Survey. Variations in the prevalence of respiratory symptoms, self-reported asthma attacks, and use of asthma medication in the European Community Respiratory Health Survey (ECRHS). Eur Respir J 1996;9:687-95.

[3] Gupta R, Sheikh A, Strachan DP, Anderson HR. Burden of allergic disease in the UK: secondary analyses of national databases. Clin Exp Aller 2004;34:520-6.

[4] Holgate ST, Ewan PW, editors. Allergy: the unmet need. London: Royal College of Physicians of London; 2003.

[5] House of Commons Health Committee. The provision of allergy services. HC 696_I. London: The Stationery Office; 2004. Available from: http://www.publications. parliament.uk/pa/cm200304/cmselect/cmhealth/696/ 69604.htm\#a3.

[6] Ewan PW, Durham SR. NHS allergy services in the UK: proposals to improve allergy care. Clin Med 2002;2:122-7.

[7] Ryan D, Levy M, Morris A, Sheikh A, Walker S. Management of allergic problems in primary care: time for a rethink? Prim Care Resp J 2005;14:195-203.

[8] General Medical Council. Tomorrow's doctors. GMC: London; 1993. Available from http://v vv.gmc-uk.org/

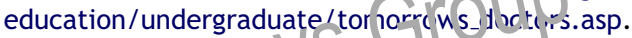

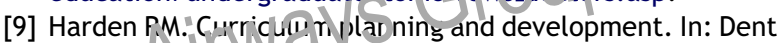
A Har ${ }^{2} n \mathrm{RN}$, euitos. A practical guide for medical eacliers. Edinburgh: Nilsevier; 2005.

[10] McKimm J J J le Cantillon P. ABC of learning and $t a c h i n g$ in niedicine: web based learning. BMJ 2003; 326:070-3.

[11] Edinburgh Electronic Medical Curriculum (visitors centre). Available from: https://www.eemec.med.ed.ac. uk/visitors/.

[12] Harden RM, Davis M. AMEE medical education guide No. 5: The core curriculum with options or special study modules. Med Teach 1995; 17:125-31.

[13] Ramsden P. Learning to teach in higher education. 2nd edition London: Routledge Falmer; 2003.

[14] Levy ML, Price D, Zheng X, Simpson C, Hannaford P, Sheikh $A$. Inadequacies in UK primary care allergy services: National survey of current provisions and perceptions of need. Clin Exp Aller 2004;34:518-9.

[15] Prideaux D. ABC of learning and teaching in medicine: curriculum design. BMJ 2003;326:268-70.

[16] Harden RM, Crosby JR, Davis MH. AMEE medical education guide No. 14: An introduction to outcome-based education. Med Teach 1999;21:7-14.

Available online at www.sciencedirect.com

science@irect.

Available online at http://www.thepcrj.com 